\title{
Sutrop on literary fiction-making: defending Currie
}

\author{
Jukka Mikkonen \\ University of Tampere
}

\begin{abstract}
In her study Fiction and Imagination: The Anthropological Function of Literature (2000), Margit Sutrop criticizes Gregory Currie's theory of fictionmaking, as presented in The Nature of Fiction (1990), for using an inappropriate conception of the author's 'fictive intention.' As Sutrop sees it, Currie is mistaken in reducing the author's fictive intention to that of achieving a certain response in the audience. In this paper, I shall discuss Sutrop's theory of fiction-making and argue that although her view is insightful in distinguishing the illocutionary effect and the perlocutionary effect in the author's fictive intention, there are flaws in it. My aim is to show that, first, Sutrop's critique of Currie's view is misguided and, second, her own definition of fiction as the author's expression of her imagination is problematic in not distinguishing literary fiction-making from other discursive functions and in dismissing the literary practice which regulates the production of literary fictions.
\end{abstract}

\section{Keywords}

Fiction, fiction-making, literature, Sutrop, Currie.

\section{Introduction}

In her work Fiction and Imagination: The Anthropological Function of Literature (2000), Margit Sutrop criticizes Gregory Currie's 'Gricean' theory of fiction-making, as presented in The Nature of Fiction (1990), for using an inappropriate conception of the author's 'fictive intention.' As Sutrop (2000: 108) sees it, Currie is mistaken in reducing the author's fictive intention to that of achieving a certain response (make-believe) in the audience. In her Searlean-based critique, Sutrop (2000: 110) maintains that the author's intention to achieve a perlocutionary effect in the audience is not necessary in fiction-making, for the author may produce fiction without intending to achieve any

Disputatio, Vol. III, No. 28, May 2010

Received on 9 February 2010 
response: she may, for instance, write for herself without having an intention to publish the work. In this paper, I shall discuss Sutrop's theory of fiction and argue that although her view is insightful in various ways, there are serious flaws in it. My aim is to show that, first, Sutrop's critique of Currie's view is misguided and, second, her own theory of fiction is problematic in not distinguishing literary fiction-making from other discursive functions.

\section{Sutrop's Critique of Currie}

Sutrop's critique of Currie's theory of fiction-making is based on John R. Searle's (see Searle 1980: 44) critique of Paul Grice's theory of meaning, in which Searle argues that Grice's theory confuses 'illocutionary' and 'perlocutionary' acts in defining meaning in terms of intended effects. Leaning on Searle, Sutrop remarks that for Grice, the intended effects of meaning are what Austin calls 'perlocutionary effect,' for instance, to produce a belief in the hearer in asserting something; according to Grice, meaning-intentions are intentions to produce a response (perlocutionary effect) in the audience. For Searle, in turn, the intended effects of meaning are 'illocutionary effects': a speaker utters a sentence and means it; according to Searle, meaning-intentions are intentions to produce an understanding (illocutionary effect) in the audience. (Sutrop 2000: 111.) After spelling out the difference between the two theories, Sutrop argues that Currie's view of the author's fictive intention as that of achieving a certain effect in the audience is limited, because an author may write fiction without intending to achieve any response. As an example, Sutrop suggests that the author may write for herself without having an intention to publish the piece. (Sutrop 2000: 110.)

\section{Sutrop's Theory of Fiction}

Sutrop's own theory of fiction is based on Currie's Gricean account supplemented with Searle's theory of intentionality as presented in Intentionality (1983). As Sutrop sees it, in performing fictional speech acts, the author 'expresses her imagination':

'The fictional speech act belongs to the class of expressives because, similarly to other expressives, its only illocutionary purpose is to express 
the speaker's mental state (specified in terms of the propositional content and psychological mode).' (Sutrop 2000: 118).

Sutrop (2000: 119) suggests that there is a difference between the author's 'intention to perform a fictive utterance and the intention to make the audience treat it as a fictive utterance.' As she sees it, there are multiple intentions involved when the sentence 'It is raining' is uttered as a part of fictional speech. In uttering the sentence, the author fulfills one condition and has total of five intentions: 1) The sincerity condition: the sincerity condition is 'imagination'; the author has the intention to express her mental state which is imagination and not belief. The author imagines that it is raining or imagines believing that it is raining. Furthermore, imagination does not have any direction of fit. 2) Meaning-intention: the author has an intention to perform a fictional speech act which belongs to the class of expressives, because its illocutionary point is to express the author's mental state. Moreover, expressives do not have any direction of fit, and different from other expressives, the truth of the proposition is not presupposed but 'bracketed.' 2.1) Representing intention: because the mental state expressed in the fictional speech act is imagination, which has null direction of fit, the author's fictional utterance does not have any direction of fit. The fictional speech act has a representational content, but that is only expressed in it. 2.2) Communication intentions: in speaking fictionally, the author may have, and often has, communication intentions but it is possible to perform a fictional utterance without communicating anything. 2.2.1) Intention to achieve an illocutionary effect: 'most likely,' the author's intention in achieving an illocutionary effect is to achieve an understanding in the audience that the speech act is not an assertion but a fictional utterance. Thus, the speaker wants to communicate that her speech act expresses her imagination and not her belief. There may be, however, cases in which the speaker has the intention to perform a fictional utterance, but has no intention to achieve the audience's understanding of the conditions under which the speech act has been performed. 2.2.2) Intention to achieve a perlocutionary effect: the author's intention in achieving a perlocutionary effect is, 'perhaps,' the intention to intend the readers to take the fictive stance or an attitude of make-believe towards the proposition expressed. The author can, nevertheless, perform fictional speech acts without intending to achieve any perlocutionary effect in the audience. (Sutrop 2000: 121-2.) As a conclu- 
sion, Sutrop (2000: 122) maintains that put in positive terms, fictional speech is 'an expression of the speaker's imagination.'

\section{Critique of Sutrop}

Although Sutrop's theory of fiction-making is subtle and insightful in analyzing the author's complex fictive intention, there are several flaws in it. First, Sutrop's critique of Currie is misguided. In her critique, Sutrop argues that Currie's theory of fiction fails, because Currie limits the author's intention to that of achieving a certain effect in the audience; nonetheless, an author may write fiction without intending to achieve any response. For Sutrop's defence, it has to be admitted that there are actually works of literary fiction which their authors did not aim, at least clearly, to be published for instance, Kafka's unfinished works and some vignettes of the Soviet writer Daniil Kharms.

However, Sutrop's thought-experiment of an author who does not intend to achieve any response does not refute Currie's theory. In his theory, Currie suggests that although his account presupposes that the author has an audience in mind, she may not have any particular audience in mind. Perhaps, Currie proposes, the author may not think of herself as guaranteed any audience. In such cases, Currie (1990: 33) thinks that the author's intention is not categorical ('that the audience shall make believe that $P$ (the propositional content of the work)') but conditional ('if anyone were $C$ (reading this book), they would make believe that $P$ '). Further, Currie supposes that there could be an author, who writes a story which she intends no one to read, not even her own future self; the author simply writes the story and burns it immediately after it has been finished. According to Currie, such an author has intended that nobody shall read her story and, consequentially, that nobody shall make-believe it. However, Currie (1990: 34) argues that such an intention does not preclude the author from intending that if one were to read it, one would make-believe it. This 'crypto-author,' as Currie calls her, intends her work to be such 'that if someone were to read it, he would make believe its content' and thus she takes her place 'among the makers of fiction by virtue of the relation of (her) activity to the activity of those with a more publicly oriented intention' (Currie 1990: 34). Hence, it can be argued that Sutrop's critique of Currie's view is actually misguided. 
Second, Sutrop own account of fiction-making is also problematic. To begin with, 'imaginary' and 'fictional' are not arguably the same. In writing these objections to Sutrop's view, I am expressing my imagination, but am I producing a fiction? In writing sticky notes in which I list things I could do on my vacation ('Drink sangria in the park?' 'Feed animals in the zoo?' 'A movie too?'), I am expressing my imagination, but am I producing a fiction or fictions ${ }^{1}$ ? In speaking an imaginary language to a child, I am expressing my imagination, but, again, am I producing a fiction? Perhaps, such schemes could be considered fictions in the sense of imaginative constructs. Nonetheless, the main problem in Sutrop's theory is that she considers the author's mode of speaking too broadly, and her definition is not distinctive of (literary) fiction-making. Different sorts of speakers perform speech acts in which they express their imagination, and Sutrop's definition, although intended to define literary fictional speech, does not provide criteria for distinguishing literary fictionmaking, such as the composing of novels and short stories, from, for instance, writing a philosophical thought-experiment (or perhaps from telling of one's own fancies or fantasies).

Further, to put away psychological phenomena such as daydreams, fancies and fantasies, it is rather odd to maintain that there could be works of fiction, at least literary fiction, without a social practice that regulates the production of and response to them. As I see it, Sutrop theory also fails in ignoring the social dimension of literary fiction and stressing the non-publishing author's individual fictive intention, which depends on or is 'parasitic' upon the social practice of literaryfictive story-telling, as she maintains that an author may write fiction without intending to achieve any response ${ }^{2}$. However, it is difficult if not impossible to conceive literary fictions - novels, short stories, poems, or plays — which would be produced without the author

\footnotetext{
${ }^{1}$ Sutrop (2000: 118) also raises this question but does not pursue it.

${ }^{2}$ Currie's view also lacks a reference to the practice of literary-fictive storytelling, and his account may be similarly criticized for ignoring the social dimension of fiction. Currie, however, implies the practice of fictive story-telling, as his expression 'publicly oriented intention' and references to the semantic and pragmatic markers of fiction suggests. Moreover, Currie (1990: 24) makes a distinction between fantasy and fiction and suggests that 'Fiction emerges ... with the practice of telling stories.' Nonetheless, he is sceptic to attempts to formulate an entire 'institutional theory of fiction' (see 1990: 10).
} 
including even the conditional intention to achieve a perlocutionary effect in her fictive utterance ('would one read this work, one would imagine rather than believe its content'). Finally, to examine Sutrop's theory as a theory of literary aesthetics, it is difficult to see what is the non-publishing author's relevance in the literary practice. After all, authors who did not publish their works are generally known by virtue of their friends, relatives, and the like, publishing their works with the intention that readers will imagine their content.

\section{Conclusion}

If the (crypto- or non-publishing) author's fictive intention is considered conditional, as Currie suggests, there is no need for modifications, as for the author's fictive intention, in the Gricean-based theories of fiction-making. However, despite its flaws, Sutrop's view is insightful in explicitly distinguishing the illocutionary effect (to achieve understanding in the audience that the utterance is not an assertion but a fictional utterance) and the perlocutionary effect (to invite the audience to take the fictive stance towards the content of the work), which Currie distinguishes only implicitly, in the author's fictive intention. Although missing in his definition of fiction-making, Currie (1990: 29) discusses the recognizing of the author's fictive intention - that she intends to achieve understanding in the audience that the work is fictional and not non-fictional - , in Gricean term of 'principle of cooperation' which is tacitly agreed to by the conversational partners, in this case, the author and audience. Further, Currie (1990: 25) suggests that the audience recognizes this part of the author's fictive intention (which might be called the categorial intention or Austinian 'illocutionary effect'), that she intends her work to be fiction and not non-fiction, by inferring the intention from the work: it is the 'only reasonable hypothesis' that makes sense of the author's utterance. As Currie (1990: 30) puts it, the author 'may expect his intention (that the audience will treat her work as a fiction) to be recognized in a number of ways: by the manner of his writing, the nature of his story, or simply because he knows his work will be advertised and sold as fiction. ${ }^{3}$ The reason why we imagine, rather

\footnotetext{
${ }^{3}$ Elsewhere, Sutrop (2002: 336) criticizes Currie (1990) by arguing that if there are no textual characteristics which all fictions have in common, how one
} 
than believe, the content of certain works is because we recognize that we are invited to do so, an intention which we infer from the works in construing them in the most reasonable manner.

$$
\begin{array}{r}
\text { Jukka Mikkonen } \\
\text { University of Tampere } \\
\text { Department of History and Philosophy } \\
33014 \text { Tampere, Finland } \\
\text { jukka.mikkonen@uta.fi }
\end{array}
$$

\section{References}

Currie, Gregory. 1990. The Nature of Fiction, Cambridge: Cambridge University Press.

Searle, John R. 1980/1969. Speech Acts. An Essay in the Philosophy of Language, Cambridge: Cambridge University Press.

Sutrop, Margit. 2000. Fiction and Imagination: The Anthropological Function of Literature, Paderborn: Mentis.

Sutrop, Margit. 2002. Imagination and the Act of Fiction-Making. Australasian Journal of Philosophy 80: 332-344.

can then recognize the author's fictive intention in the text? (For Sutrop's view of 'reliable signs' of the author's fictive intention, see ibid. 337-8.) However, Currie does not claim that there would be textual characteristics which all fictions have in common; instead, he (1990: 30) suggests that there are semantic and pragmatic markers for fiction. 